\title{
UKRAINA MIEDZY WSCHODEM A ZACHODEM. STANOWISKO POLSKI WOBEC AKCESJI UKRAINY DO NATO I UNII EUROPEJSKIEJ
}

\section{Ukraine between the East and the West: Poland's Position on Ukraine's Accession to NATO and the European Union}

In this article, the author analyses Ukraine's international policy and particularly its balancing between the East and the West from the moment of its declaration of independence in 1991 to the present day. He states that Ukraine's foreign policy fluctuates between Russian (eastern) and transatlantic (western) orientations. In the author's opinion, this difficult choice is determined by many factors, including historical, cultural, social, economic and international ones. Moreover, the author presents the position of Poland towards this still unsolved Ukrainian dilemma and towards Ukraine's accession to NATO and the European Union. The main thesis of this article is the author's conclusion that the imperial international policy of Russia under President Vladimir Putin and the passive stance of NATO, the European Union and the United States have exerted a particular influence on Ukraine's foreign policy and the position of Poland towards its Euro-Atlantic aspirations. Being afraid of Russia, the West in a broad sense has come to terms with its aggressive policy towards Ukraine and has forgotten about Crimea. It cares about its economic cooperation with Russia more than about the security of Ukraine and Poland.

Keywords: Ukraine, Poland, Russia, NATO, European Union, accession, East, West, security. 


\section{WSTEP}

Celem niniejszego opracowania jest próba pokazania dylematu suwerennej Ukrainy, który występuje w jej polityce zagranicznej od 1991 roku - de facto do dnia dzisiejszego. Dotyczy on wyboru strategicznych kierunków rozwoju Ukrainy i jej współpracy tak ze Wschodem, jaki i Zachodem, a co w praktyce sprowadza się do wyboru między Rosją i Unią Europejską oraz między UE i Unią Eurazjatycką Władimira Putina. Dylemat, czy ubiegać się o akcesję do NATO i Unii Europejskiej, czy też zacieśniać współpracę z Rosja, jest widoczny w polityce wewnętrznej i zagranicznej Ukrainy od momentu ogłoszenia jej niepodległości w 1991 roku i wciąz - moim zdaniem - nie jest ostatecznie rozwiazany. Ponadto w opracowaniu tym chciałbym przedstawić stanowisko Polski wobec ukraińskiego dylematu oraz wobec akcesji Ukrainy do NATO i Unii Europejskiej. Zamierzam także odpowiedzieć na kilka pytań $z$ tym związanych, m.in. która $z$ tych opcji jest korzystniejsza dla Ukrainy - zachodnia czy wschodnia oraz która $z$ nich jest korzystniejsza dla Polski i jej racji stanu. Czy może jest inna, lepsza droga wyboru dla Ukrainy, optymalna dla jej racji stanu oraz dla bezpieczeństwa Polski i Europy? Dla całości rozważań przyjąłem hipotezę badawczą zakładająca, że zachodzące zmiany w środowisku międzynarodowym Polski i Ukrainy oraz $\mathrm{w}$ ich relacjach multilateralnych i bilateralnych powoduja, że dziś konieczna jest rewizja i korekta kierunków (wektorów) ich dotychczasowej polityki zagranicznej. Dotychczasowy bowiem kurs w polsko-ukraińskich relacjach, a zwłaszcza od lat 2014-2015 w polityce międzynarodowej obydwu państw doprowadził do ich osłabienia oraz izolacji na arenie międzynarodowej. Złożyło się na to wiele przyczyn tak wewnętrznych, jak i zewnętrznych, a szczególny wpływ zarówno na politykę zagraniczna Ukrainy i stanowisko Polski wobec jej euroatlantyckich aspiracji wywiera - moim zdaniem - imperialna polityka międzynarodowa Rosji pod rządami prezydenta Władimira Putina i bierne wobec niej stanowisko zarówno NATO, jak i Unii Europejskiej oraz Stanów Zjednoczonych. Szeroko rozumiany Zachód, który boi się Rosji, pogodził się z jej agresywną polityką wobec Ukrainy i zapomniał o Krymie. Zależy mu bardziej na współpracy gospodarczej z Moskwa niż na bezpieczeństwie Ukrainy i Polski. Widać wyraźnie, że idea współpracy między państwami członkowskimi UE, dotychczas opierajaca się na liberalizmie międzyrządowym, traci na znaczeniu wobec tradycyjnego podejścia realistycznego w stosunkach międzynarodowych. Różnice w bilateralnych relacjach między 
poszczególnymi państwami członkowskimi UE a Rosja wskazuja na odchodzenie od pogłębionej współpracy na poziomie ponadnarodowym. Dotychczasowa współpraca opierała się na paradygmacie liberalnym w stosunkach międzyrządowych - wzmocniona kooperacja miała przyczynić się do zwiększenia bezpieczeństwa oraz przeciwdziałania i reagowania na zagrożenia stojące przed Unia Europejską. Jednak w kontekście kryzysu wschodniego, wywołanego agresją Rosji na Ukrainę, coraz wyraźniej obserwuje się odchodzenie od współpracy na poziomie wspólnotowym i zwrot ku koncentracji na interesach narodowych. Wartości takie jak solidarność, demokracja czy pokojowa współpraca nie są traktowane jako zasady nadrzędne w stosunku do gospodarczych interesów narodowych. Państwa współpracuja ze soba w celu maksymalizacji własnego zysku, pomijajac w tym zakresie przyjęty przez Unię Europejską system aksjologiczny. Taki model współpracy jest właściwy tradycyjnemu podejściu realistycznemu w stosunkach międzynarodowych. Zauważalny jest także brak wspólnego stanowiska politycznego wszystkich państw członkowskich UE i NATO oraz przejrzystej i zdecydowanej strategii bezpieczeństwa dla Europy i świata. Taka strategia powinna umożliwić wykorzystywanie odpowiednich środków i instrumentów w czasie kryzysu, w tym przypadku w stosunku do Ukrainy i Rosji ${ }^{1}$.

Zdaniem niektórych ekspertów, optymalnym, korzystnym dla wszystkich zainteresowanych stron, zwłaszcza dla Polski i Ukrainy, byłby taki stan, w którym Ukraina byłaby:

[...] politycznym sojusznikiem w możliwie szerokim spektrum spraw, zakotwiczonym w strukturach NATO i UE, względnie w innych sojuszach, których Rzeczpospolita będzie uczestnikiem. Krajem, w którym polskie firmy będą mocno obecne, obie strony będą dla siebie kluczowymi partnerami handlowymi, a kultura polska będzie rozpowszechniona. Państwem, które odzyska okupowane przez Rosję tereny - Krym i część Donbasu².

Niestety, moim zdaniem, to tylko pobożne życzenia, dziś i w perspektywie nawet dwudziestu pięciu lat trudne do spełnienia. Nie uwzględniają bowiem roli Rosji rosnącej w siłę i stajaccą się ważnym graczem na arenie międzynarodowej, $z$ którego stanowiskiem muszą

1 P. Olszewski, Unia Europejska $w$ świecie. Od liberalizmu do realizmu, Instytut Studiów Politycznych PAN, Warszawa 2018; J. Czaputowicz, Bezpieczeństwo międzynarodowe: wspókczesne koncepcje, Wydawnictwo Naukowe PWN, Warszawa 2012; J. Kiwerska, Ukraina $i$ stosunki transatlantyckie, „Rocznik Integracji Europejskiej” 2015, nr 9, s. 345-363.

2 Ł. Adamski, W. Konończuk, Nowy dialog z Ukraina, „Rzeczpospolita”, 18 III 2019, s. A10. 
liczyć się pozostałe mocarstwa uczestniczące w procesie kształtowania się nowego, multipolarnego ładu globalnego, który - moim zdaniem uformuje się w połowie XXI wieku, a Rosja obok Stanów Zjednoczonych i Chin będzie odgrywała w nim główna rolę. Natomiast Polska, Ukraina i Europa będa co najwyżej jego peryferiami ${ }^{3}$.

\section{UKRAINA MIĘDZY WSCHODEM A ZACHODEM}

Nie ulega watpliwości, że poczynając od 1991 roku, czyli od uzyskania niepodległości Ukraina przeżywa wielki dylemat, a może nawet polityczny dramat, jeśli idzie o wybór strategii rozwoju jako suwerennego i demokratycznego państwa. W polityce zagranicznej waha się między orientacją rosyjska (wschodnia) i unijna (zachodnia). Ten trudny dla niej wybór determinowany jest wieloma przesłankami, m.in. historycznymi, kulturowymi, społecznymi oraz gospodarczymi i międzynarodowymi. Nie bez znaczenia były i sa nadal dla Ukrainy uwarunkowania geopolityczne i geoekonomiczne, w tym zwłaszcza jej silne powiązania $z$ potężnym sąsiadem, czyli Federacją Rosyjską, która po rozpadzie Związu Radzieckiego cały czas również szuka dla siebie nowego miejsca na zmieniającej się mapie politycznej Europy i świata oraz balansuje między Wschodem a Zachodem. Rosja, która po utracie w 1991 roku Ukrainy i republik nadbałtyckich (Litwy, Łotwy i Estonii) przestała być mocarstwem morskim, stała się zaledwie mocarstwem regionalnym. To zaś dla większości rosyjskich elit politycznych na czele $z$ Władimirem Putinem było na dłuższą metę nie do zaakceptowania. Rosja, po odejściu w 1999 roku niezdecydowanego i słabego prezydenta Borysa Jelcyna podjęła pod rządami Putina wysiłki na rzecz odbudowy swojej pozycji na arenie międzynarodowej jako potęgi globalnej. Na drodze Rosji do statusu supermocarstwa światowego nolens volens stała i stoi nadal Ukraina, która w 1991 roku rozpoczęła proces transformacji i budowę państwa demokratycznego $z$ wolnorynkowa gospodarka oraz obrała kurs na współpracę z Zachodem, w tym również $z$ Wspólnotami Europejskimi, Stanami Zjednoczonymi, Polską i Federacją Rosyjską. Niepodległa Ukraina, która w czasach

3 J.M. Fiszer, System euroatlantycki przed i po zakończeniu zimnej wojny. Istota, cele $i$ zadania oraz rola $w$ budowie nowego ładu globalnego, Instytut Studiów Politycznych PAN, Dom Wydawniczy Elipsa, Warszawa 2013; J.M. Fiszer, Niemcy i Francja w Unii Europejskiej po brexicie, „Rocznik Polsko-Niemiecki” 2018, nr 26, s. 39-55; R. Kuźniar, Europa w porzadku międzynarodowym, Polski Instytut Spraw Międzynarodowych, Warszawa 2016; B. Góralczyk, Wielki renesans. Chińska transformacja $i$ jej konsekwencje, Wydawnictwo Akademickie Dialog, Warszawa 2018. 
Związku Radzieckiego stanowiła jeden $z$ głównych filarów jego potęgi gospodarczej (surowce naturalne, przemysł ciężki, rolnictwo) i wojskowej (przemysł zbrojny, bazy wojskowe, w tym morskie i broń atomowa rozlokowana na jej terytorium) obecnie dla Rosji, zwłaszcza pod rzadami Putina i jego geopolitycznych wizji, stała się wręcz niezbędna ${ }^{4}$. W rezultacie tego doszło tutaj do zderzenia rosyjskiej geopolityki i geoekonomii z geopolityką i geoekonomią Ukrainy, państwami ściśle ze soba powiązanymi, wręcz dla siebie niezbędnymi.

W przeciwieństwie jednak do Rosji, Ukraina w dłuższej perspektywie i przy współpracy z Unią Europejską mogłaby stanąc na własnych nogach i uniezależnić się od Moskwy, a to pokrzyżowałoby, wręcz uniemożliwiłoby Putinowi odbudowę Rosji jako mocarstwa globalnego, zdolnego konkurować ze Stanami Zjednoczonymi i mocarstwami wschodzacymi $z$ Chinami na czele o hegemonię nad światem. Moim zdaniem, to właśnie tutaj należy szukać źródeł obecnego konfliktu między Rosją a Ukrainą. Jest to jedna $z$ głównych tez niniejszego opracowania. Kolejna teza, która dotyczy perspektyw Ukrainy, jest konstatacja, że przesłanki geopolityczne i geoekonomiczne skazują Ukrainę na rozwój współpracy zarówno $z$ Unią Europejska (Zachodem), jak i z Rosją (Wschodem), czy to się komuś podoba, czy nie. Teza ta wynika $z$ paradygmatu realistycznego, wykorzystanego do analizy powyższego problemu oraz jest determinowana doświadczeniami historycznymi i współczesna sytuacja geopolityczną w Europie i na świecie oraz realiami geoekonomicznymi Ukrainy. Im szybciej zdadzą sobie $z$ tego sprawę wszystkie strony zaangażowane w rozwiązanie konfliktu rosyjsko-ukraińskiego, tym lepiej będzie dla Ukrainy, Rosji, Polski, Unii Europejskiej i całego świata, dla pokoju i bezpieczeństwa międzynarodowego.

W dalszej części opracowania spróbuję odpowiedzieć na pytania, czy i w jaki sposób geopolityczne i geoekonomiczne uwarunkowania determinuja politykę wewnętrzna i zagraniczna Ukrainy oraz $\mathrm{w}$ jakim stopniu wpływaja na jej europeizację oraz na stosunki z Polska, Unią Europejską i Federacją Rosyjską. Spróbuję odpowiedzieć też na pytanie, czy geopolityka i geoekonomika ułatwiają Ukrainie „powrót” do Europy, jak to było w przypadku Polski po 1989 roku ${ }^{5}$, lub

$4 \quad$ K. Świder, A. Stec, T.Z. Leszczyński (red.), Współczesna Ukraina - trwałość czy rozpad?, Polskie Towarzystwo Geopolityczne, Warszawa-Kraków 2015, s. 17-33; T. Olszański, Trud niepodległości. Ukraina na przełomie tysiącleci, Instytut Studiów Strategicznych, Kraków 2003.

5 J.M. Fiszer, Polityka zagraniczna Polski $w$ XXI wieku: cele, wyzwania, kierunki, szanse i zagrożenia, „Myśl Ekonomiczna i Polityczna” 2019, nr 2(65), s. 142-172. 
odwrotnie - utrudniają? I vice versa, zamierzam przedstawić, czy i jak geopolityka i geoekonomika Rosji wpływa na jej politykę wobec całego obszaru poradzieckiego, a zwłaszcza na stosunki z Ukraina, Polską i z Unią Europejską. Ponadto spróbuję pokazać perspektywy dla Ukrainy, której władze od 1991 roku lawirujac między Rosja a Unią Europejska, w rezultacie takiej polityki zadłużyły kraj na niebotyczną sumę i są współodpowiedzialne za wybuch konfliktu z Rosją na przełomie 2013 i 2014 roku. Kraj ten od 1991 roku aż do eurorewolucji na Majdanie Niezależności w Kijowie ${ }^{6}$ nominalnie szedł na Zachód, jednak nie robił nic, by poważnie przeciwstawić się Rosji. Warto tutaj wspomnieć, że podobna politykę po 1991 roku prowadziły Armenia, Mołdawia i Białoruś, które ostatecznie - pod naciskiem Rosji - przystapiły do utworzonej przez prezydenta Władimira Putina Unii Eurazjatyckiej ${ }^{7}$.

Uważam jednak, że również Unia Europejska i NATO nie sa bez winy, jeśli idzie o konflikt między Ukrainą a Rosją. Unia niepotrzebnie składała Ukrainie obietnice bez pokrycia i niemożliwe do urzeczywistnienia w praktyce, co tylko rozbudziło wielkie nadzieje Ukraińców na rychłe członkostwo w UE i NATO, a Rosję popchnęło do działań, które miały temu zapobiec. Dziś Unia i NATO powinny uczynić wszystko, aby jak najszybciej doszło do normalizacji stosunków między tymi państwami i wypracować właściwą strategię zarówno wobec Rosji, jak i Ukrainy. To zaś wymaga współpracy UE i Stanów Zjednoczonych nie tylko $z$ Ukraina, ale również $z$ Rosja, bez której nie jest możliwe pokojowe zakończenie ukraińsko-rosyjskiego konfliktu ${ }^{8}$. Nie oznacza to jednak, że Zachód musi we wszystkim ulegać Rosji i od razu przyjmować Ukrainę w poczet członków Unii i NATO, czy też znieść sankcje wobec Rosji. Ukraina musi bowiem bardzo dobrze przygotować się do członkostwa w obu tych organizacjach, aby nie stać się przysło-

6 Eurorewolucja na Majdanie to dramatyczne wydarzenia mające miejsce na Ukrainie, głównie w Kijowie na Majdanie Niezależności między 21 listopada 2013 roku a 22 lutego 2014 roku. Zostały rozpoczęte $z$ chwilą ogłoszenia przez rząd premiera Mykoły Azarowa, że Ukraina nie podpisze umowy o stowarzyszeniu Ukrainy z Unią Europejską, a zakończyły się wraz z odsunięciem od władzy prezydenta Wiktora Janukowycza. Pociagnęły za soba ponad sto ofiar zabitych i kilkaset rannych.

7 J.M. Fiszer, Białoruś między Rosja i Unia Europejska - konflikt interesów i perspektywy współpracy, w: A. Kantorowicz (red.), Białoruś między Unią Europejska a Rosja, Akademia Finansów i Biznesu Vistula w Warszawie, Warszawa 2012, s. 19-41; J. Ćwiek -Karpowicz, Rosja wobec Białorusi. Ekonomizacja polityki zagranicznej, „Polski Przegląd Dyplomatyczny" 2010, nr 5-6, s. 119-121.

8 R. Zięba, Międzynarodowe implikacje kryzysu ukraińskiego, „Stosunki Międzynarodowe - International Relations”, nr 2 (t. 50); B. Góralczyk, Unia Europejska jako aktor na scenie globalnej. Razem czy osobno? Centrum Europejskie Uniwersytetu Warszawskiego, Warszawa 2014. 
wiowym koniem trojańskim dla systemu euroatlantyckiego. Wzorem może być Polska i jej droga do NATO i Unii Europejskiej. Decydujący wpływ na członkostwo naszego kraju w tych organizacjach miała ówczesna sytuacja międzynarodowa i zdecydowana, konsekwentna postawa Polski i jej prozachodnia polityka zagraniczna. Istotny wpływ na akcesję Polski do NATO i UE miało także stanowisko Zachodu, a zwłaszcza Stanów Zjednoczonych, Francji i Niemiec ${ }^{9}$.

Dziś, po 31 latach od rozpoczęcia transformacji ustrojowej w Polsce, 21 latach od wstapienia do NATO i po 16 latach od akcesji do Unii Europejskiej nie ulega wątpliwości, że nasze członkostwo w strukturach systemu euroatlantyckiego było konieczne i nieuniknione. Przyczyniło się do reorientacji polityki zagranicznej Polski i zapewniło jej bezpieczeństwo oraz wysoka pozycję na arenie międzynarodowej. Było to jedyne, racjonalne rozwiazanie dla postkomunistycznej Polski i jej polityki zagranicznej, które wynikło $z$ jej nowej sytuacji geopolitycznej i geoekonomicznej powstałej po zakończeniu zimnej wojny w Europie i na świecie. Odrzucenie członkostwa w NATO i UE skutkowałoby redukcją naszych możliwości i szans na odgrywanie istotnej roli zarówno w polityce europejskiej, jak i światowej. Polska bowiem nadal znajdowałaby się w mało stabilnej strefie pomiędzy Zachodem a obszarem poradzieckim, a jej bezpieczeństwo narodowe i międzynarodowe byłoby poważnie zagrożone, zwłaszcza $z$ powodu narastającej od początku XXI wieku neoimperialnej polityki Rosji.

Ukraina jako państwo peryferyjne, rozerwane między Wschodem i Zachodem, którego pozycja znajduje się poza rdzeniem społeczności międzynarodowej, w obecnej sytuacji w Europie i na świecie powinna prowadzić realistyczna politykę, tzn. nie ulegać złudzeniom i twardo stapać po ziemi. Członkostwo w NATO i UE powinno być celem strategicznym ukraińskiej polityki zagranicznej. Przede wszystkim Ukraina musi współpracować z Polska, Stanami Zjednoczonymi, UE i Niemcami oraz porozumieć się z Rosją i zakończyć trwający od 2014 roku konflikt, który uniemożliwia jej akcesję do UE i NATO. Rosja i Ukraina oficjalnie nie sa w stanie wojny. Nie zmienia to jednak faktu, że obecnie na terytorium Ukrainy trwa tzw. wojna hybrydowa, polegajaca na wykorzystaniu elementów wojny konwencjonalnej połączonych z elementami wojny nieregularnej. Krótko mówiąc, jest to współczesny typ wojny partyzanckiej, prowadzonej przy użyciu współczesnych

9 J.M. Fiszer, Stanowisko Rosji wobec akcesji Polski do NATO i Unii Europejskiej, „Myś1 Ekonomiczna i Polityczna" 2018, nr 1(60), s. 264-289; P. Wieczorek, P. Kłudka, Droga Polski do NATO - próba bilansu, Wydawnictwo MON, Warszawa 1997. 
technologii wojskowych i metod mobilizujacych. Wojna hybrydowa prowadzona, tak jak w przypadku działań na wschodniej granicy Ukrainy, bez oficjalnej deklaracji jej wszczęcia, jest niezwykle agresywnym i kosztownym typem walki, który w przypadku zakończenia konfliktu pozwala na uniknięcie odpowiedzialności prawnomiędzynarodowej przez agresora.

Konflikt ukraińsko-rosyjski wpłynął na znaczne zaostrzenie sytuacji międzynarodowej w Europie, która jest niekorzystna także dla Polski. Kraje takie jak Ukraina i Białoruś sa traktowane przez Rosję jako strefa buforowa. Uważa ona, że NATO i UE niebezpiecznie zbliżaja się do jej granic. Także niektórzy eksperci zachodni uważaja, że ogłaszając na bukareszteńskim szczycie NATO w kwietniu 2008 roku przyjęcie w przyszłości w jego skład Gruzji i Ukrainy, Sojusz przekroczył „czerwoną linię”. Sprowokowało to Rosję do działań mających temu zapobiec i doprowadziło do wojny z Gruzja w 2008 roku. Niestety, reakcja Zachodu wobec agresywnych działań Rosji w Gruzji była zbyt słaba i mało skuteczna. Nie zastosowano bowiem wobec Rosji żadnych sankcji karnych, co tylko rozzuchwaliło Putina i stało się jedna $z$ przesłanek do aneksji przez Rosję Krymu na przełomie lutego i marca 2014 roku. Wielu ekspertów i polityków uważa, że właśnie ówczesna słaba reakcja Zachodu, a zwłaszcza Stanów Zjednoczonych wobec Rosji rozzuchwaliła Putina, który, przygotowując się do wojny z Ukraina, mógł zakładać, że i tym razem świat zachodni nie przyjdzie Ukrainie $z$ pomoca i nie podejmie nieprzyjemnych dla Rosji działan ${ }^{10}$.

W kontekście powyższego, zgadzam się w całości ze stanowiskiem Aleksandra Milinkiewicza ${ }^{11}$, który jesienią 2013 roku pisał, że:

Unia Europejska winna dokonać poważnej analizy swojej polityki wschodniej - nie da się bowiem już nie zauważyć negatywnych tendencji i oczywistych porażek. Konieczne sa opracowanie i realizacja nowej strategii majacej na celu wzmocnienie demokracji i zachowanie stabilności naszej części kontynentu. Sytuacja geopolityczna zmienia się bowiem na gorsze - wzmocnieniu ulega rosyjski rewanżyzm, który jest zarazem antydemokratyczny i neoimperialny. Bruksela powinna więc wdrożyć oparta na twardych realiach strategię, której podstawa musza być konkretne działania, a nie retoryka. Działania, a nie wyrażanie, choćby i najpiękniejszych, uczuć. Trudno uciec od konstatacji, że Partnerstwo Wschodnie nie ma zbyt wielu sukcesów - Kreml skutecznie neutralizuje powyższa inicjatywę, nie żałując przy tym sił i środków na to, by wciagnąc państwa PW w sferę swoich wpływów. W Rosji wszelka aktywność

10 J. Kiwerska, Ukraina $i$ stosunki transatlantyckie..., s. 352-353.

11 Aleksander Milinkiewicz, kandydat w wyborach prezydenckich na Białorusi w 2006 roku, opozycjonista, lider ruchu „O wolność". 
służy polityce - w Europie polityka ma pobudzać aktywność. Trzeba to rozumieć, by pojąć skalę wyzwania ${ }^{12}$.

Reakcja Zachodu, a zwłaszcza Stanów Zjednoczonych wobec Rosji po aneksji Krymu w 2014 roku, która stanowiła jawne pogwałcenie suwerenności Ukrainy i naruszenie zasad prawa międzynarodowego, była tym razem dość ostra i niewątpliwie zaskoczyła Putina. Jak pisze Jadwiga Kiwerska:

Prezydent Obama, w pierwszej reakcji na zbrojna operację krymska, zapowiadał, że Rosja „zapłaci cenę za agresją przeciwko Ukrainie”, zaś sekretarz stanu John Kerry słał komunikat, że „Rosja dokonuje aktu agresji i łamie prawo międzynarodowe”, a potem groził, że „będziemy ją izolować politycznie i ekonomicznie, jeśli nie zaprzestanie inwazji na Ukrainę". Jeszcze mocniej brzmiały słowa wypowiadane przez polityków z opozycyjnej Partii Republikańskiej [...], którzy „zarzucali gospodarzowi Białego Domu zbyt łagodne dotąd traktowanie rosyjskiego przywódcy ${ }^{13}$.

W ślad za tymi oświadczeniami poszły konkretne działania Zachodu wobec Rosji w postaci różnego rodzaju sankcji finansowo-gospodarczych i politycznych, na czym w dużym stopniu skorzystała Ukraina, która otrzymała spora pomoc, zwłaszcza finansowa, od Stanów Zjednoczonych. Rosja m.in. została wykluczona $z$ grona państw G-8, a w Waszyngtonie i Brukseli uznano, że Ukraina ma kluczowe znaczenie dla bezpieczeństwa Europy, a zwłaszcza jej wschodniej części. Pojawiło się więc zielone światło dla akcesji Ukrainy do NATO i Unii Europejskiej, ale niestety Zachód, a zwłaszcza takie kraje UE, jak Niemcy, Francja, Węgry, Bułgaria i Słowacja, które na współpracy gospodarczej z Rosja zarabiały krocie lub były uzależnione od rosyjskich tanich surowców, zachowywały się niekonsekwentnie wobec Moskwy i sprzeciwiały się akcesji Ukrainy do Unii Europejskiej i NATO. Konflikt na Ukrainie ujawnił głębokie podziały we wspólnocie euroatlantyckiej, a zwłaszcza obnażył słabość UE zarówno w działaniach ekonomicznych, jak i politycznych wobec Rosji. UE okazała się struktura mało koherentną i niezdecydowana. Oceny tej - jak pisze Jadwiga Kiwerska - „nie zmieniło zasadniczo podpisanie przez Unię Europejską z Ukraina w czerwcu 2014 r. specjalnej umowy stowarzyszeniowej, najpierw jej części politycznej, a następnie handlowej"14.

12 A. Milinkiewicz, Nie zrobicie z Łukaszenki demokraty, ale nie odwracajcie się od nas. Europa na Wschód, „Gazeta Wyborcza”, 16 X 2013, s. A7.

13 J. Kiwerska, Ukraina i stosunki transatlantyckie..., s. 353-354.

14 Ibidem, s. 356-357. 
Sytuacja ta zmieniła się dopiero po zestrzeleniu w lipcu 2014 roku przez rosyjskich separatystów nad Ukraina malezyjskiego samolotu z 298 pasażerami na pokładzie. UE solidarnie zdecydowała się wówczas na zastosowanie radykalnych sankcji gospodarczych, finansowych i personalnych wobec Rosji, które sa sukcesywnie przedłużane do dnia dzisiejszego. W ślad za tym, podczas szczytu NATO na początku września 2014 roku w Newport, podjęta została decyzja o utworzeniu tzw. szpicy NATO, czyli nowych sił szybkiego reagowania i wzmocnienia tzw. wschodniej flanki Paktu, majacej na celu zapewnienie bezpieczeństwa państwom Europy Wschodniej i ich obronę przed agresywna polityką Putina ${ }^{15}$. Dzięki temu nastapiło skonsolidowanie i wzmocnienie sojuszu transatlantyckiego, który skutecznie ogranicza agresywna politykę Moskwy i pośrednio chroni Ukrainę przed Rosją.

\section{STANOWISKO POLSKI WOBEC AKCESJI UKRAINY DO NATO I UNII EUROPEJSKIEJ}

Polska konsekwentnie od lat 90 . XX wieku popiera politykę rozszerzania NATO i UE na Wschód, a zwłaszcza popiera akcesję Ukrainy do struktur euroatlantyckich, zdając sobie sprawę $z$ tego, że naraża się na gniew Rosji i jej antypolska politykę. Mimo to Polska, tak jak po 1989 roku Niemcy wobec nas, stara się być adwokatem Ukrainy w jej wysiłkach na rzecz członkostwa w NATO i UE, choć nie zawsze było i jest to doceniane w Kijowie. Polityka Polski i nasza pomoc dla Ukrainy po 1991 roku, z którą wiązaliśmy duże nadzieje geopolityczne i geoekonomiczne, nie zawsze przynosiła oczekiwane rezultaty. Przyczyny tego stanu rzeczy były różne. Polska kładła nacisk na transformację ustrojową i integrację ze strukturami euroatlantyckimi oraz zabiegała o akcesję do NATO i Wspólnot Europejskich. Natomiast Ukraina w tym czasie upajała się niepodległością i powoli rozstawała się z Rosją, sukcesorką Zwiąku Radzieckiego, oraz starała się umocnić swoja pozycję na arenie międzynarodowej, prowadząc jednak niezdecydowaną politykę na kierunku zachodnim, gdyż wciąż mocno była uzależniona od Rosji, zwłaszcza w aspekcie gospodarczym i społecznym.

Poczynając od lat 2014-2015 w relacjach polsko-ukraińskich zaczęły narastać problemy i różnego rodzaju turbulencje. Przyczyny tego stanu rzeczy sa złożone i leżą po obydwóch stronach. Jedną $z$ nich stała się polityka historyczna. Wojna $z$ pomnikami i o pomniki nie po-

15 J. Stoltenberg, NATO Rosji się nie boi, „Gazeta Wyborcza”, 6 X 2014. 
winna mieć miejsca w stosunkach polsko-ukraińskich, a także w stosunkach polsko-rosyjskich i rosyjsko-ukraińskich. Umacniając swoją tożsamość narodowa, co czyni Ukraina i Rosja, nie należy jednak gloryfikować zasług i czynić bohaterami narodowymi osób, które dla Polski były zbrodniarzami, jak na przykład Stepan Bandera czy Józef Stalin, i są odpowiedzialni za wymordowanie setek tysięcy Polaków na Wołyniu i Syberii, w Katyniu, Starobielsku czy Ostaszkowie ${ }^{16}$.

W Strategii Bezpieczeństwa Narodowego Rzeczypospolitej Polskiej z 5 listopada 2014 roku podkreślono, że:

Odbudowywanie mocarstwowości Rosji kosztem jej otoczenia oraz nasilania się jej konfrontacyjnej polityki, czego przykładem jest konflikt z Ukraina, w tym aneksja Krymu, negatywnie rzutuje na stan bezpieczeństwa w regionie.

\section{Niektórzy badacze uważają jednak, że:}

Polskie elity polityczne postrzegaja Rosję przez pryzmat złych doświadczeń historycznych. Nie mając realistycznej koncepcji polityki wschodniej, przypisuja Rosji neoimperialne i antypolskie ambicje, co w pewnym stopniu stanowi samospełniająca się prognozę. Od drugiej połowy pierwszej dekady obecnego stulecia Moskwa coraz śmielej przeciwstawia się hegemonii amerykańskiej i polityce odpychania Rosji od Europy ${ }^{17}$.

\section{Trudno mi się zgodzić $z$ taką ocena polityki zagranicznej Rosji.}

Moim zdaniem, Polska wspierając i aktywnie angażując się w kwestię demokratyzacji i europeizacji Ukrainy, jej członkostwa w NATO oraz UE, nie doceniła jednak:

[...] postrzegania miejsca i roli Ukrainy w procesie odbudowy rosyjskiego imperium. Wśród rosyjskich elit politycznych dominuje bowiem przekonanie, że większe niebezpieczeństwo grozi ich krajowi w wyniku potencjalnego rozpadu wewnętrznego niż napaści zewnętrznej. [Dlatego też] w przewrocie na Majdanie w Kijowie Rosja dostrzegła dwa niebezpieczeństwa. Po pierwsze, gniew ludu może doprowadzić do zmiany władzy. Po drugie, jeśli reformy na Ukrainie się powioda, to dla milionów Rosjan będzie to dowodem, że mogą one również powieść się w Rosji ${ }^{18}$.

16 T. Stępniewski, Miejsce Ukrainy w polityce wschodniej Polski po 2004 roku, „Sprawy Międzynarodowe" 2018, nr 3, s. 188-189; J.M. Fiszer, T. Stępniewski, Polska i Ukraina $w$ procesie transformacji, integracji i wyzwan dla bezpieczeństwa Europy Środkowo-Wschodniej, Instytut Studiów Politycznych PAN, Warszawa 2017; G. Motyka, Od rzezi wołyńskiej do akcji „Wisła”. Konflikt polsko-ukrainski 1943-1947, Wydawnictwo Literackie, Kraków 2011; tenże, Wolyń '43. Ludobójcza czystka - fakty, analogie, polityka historyczna, Wydawnictwo Literackie, Kraków 2016.

17 R. Zięba, Polityka zagraniczna Polski..., s. 449. Zob. także: R. Zięba, Uwarunkowania polityki zagranicznej Polski na początku drugiej dekady XXI wieku, „Stosunki Międzynarodowe - International Relations" 2011, nr 1-2 (t. 43).

18 A.D. Rotfeld, Relacje Polska - Rosja - Ukraina a zmieniajacy się ład międzynarodowy, „Sprawy Międzynarodowe” 2018, nr 1, s. 24. 
W związku z tym, mimo zaangażowania się Zachodu w „pomarańczową rewolucję" na Ukrainie w 2004 roku oraz obecności wśród protestujących na Majdanie w latach 2013-2014 także wielu Polaków, szanse na demokratyzację Ukrainy i jej członkostwo w UE i NATO w perspektywie krótko- i średniookresowej należy uznać za nikłe. Rosja bowiem będzie nadal destabilizować Ukrainę i torpedować jej prozachodnia politykę. Co prawda, nałożone przez Zachód na Rosję sankcje i poparcie dla Ukrainy umożliwiły jej przeprowadzenie wielu reform polityczno-gospodarczych i przebudowę państwa, ale wciąż kraj ten nie spełnia standardów obowiąujących w UE i NATO ${ }^{19}$.

Zajmując nieprzejednane stanowisko wobec Rosji i krytykując zawarte w latach 2014-2015 porozumienia mińskie, które miały zakończyć zbrojny konflikt w Donbasie, Polska rozluźniła swoje stosunki $z$ Niemcami i Francją. Co więcej, utraciła też status wspomnianego „adwokata” Ukrainy w NATO i UE na rzecz Niemiec, a to sprzyja rozwojowi ich współpracy z Rosją. Zacieśniające się dziś relacje Niemiec i Rosji stanowia poważne zagrożenie dla bezpieczeństwa Polski. W takiej sytuacji Warszawa powinna przewartościować swoją politykę wobec Ukrainy i zastanowić się, czy nie lepiej zacieśnić swoich stosunków z Niemcami na rzecz wspólnego kreowania polityki wschodniej UE, która dziś znajduje się w głębokim kryzysie. Polityka zagraniczna Polski, w tym także polityka wschodnia, powinna być aktywna i swym zasięgiem daleko wykraczać poza Europę. Powinna być oparta na systemie euroatlantyckim i bliskich relacjach z Niemcami, Francja, Wielką Brytanią i Stanami Zjednoczonymi. Ważna rolę powinna też w polskiej polityce międzynarodowej odgrywać współpraca z krajami Grupy Wyszehradzkiej i w ramach Trójkata Weimarskiego. Polska polityka zagraniczna powinna również zmierzać do naprawy stosunków z Ukraina, Rosją i Chinami, które w XXI wieku obok Stanów Zjednoczonych będa odgrywały ważną rolę na arenie międzynarodowej i w procesie budowy nowego ładu globalnego.

Niestety, Polska od 2015 roku przestała włączać się w inicjatywy dotyczace europejskiej polityki wschodniej. Od dłuższego czasu MSZ nie organizuje i nie bierze udziału w wielostronnych wizytach w Kiszyniowie, Mińsku, a nawet Kijowie. Nie uczestniczy też w projektowaniu i implementowaniu unijnego wsparcia dla Ukrainy. Tłumaczenie tej sytuacji słabościa polskiej dyplomacji pokazuje tylko część prawdy.

19 Z. Parafianowicz, Fikcyjne partnerstwo. Bilans rzadów Petro Poroszenki, „Dziennik Gazeta Prawna”, 29-31 III 2019, s. A10-A11; R. Szoszyn, Zelenski wypowiada wojnę mafii, „Rzeczpospolita”, 3 IX 2019, s. A8. 
Przyczyny leżą bowiem dużo głębiej - polska polityka utraciła wspólny mianownik z celami polityki unijnej. Od samego początku, czyli od momentu rozszerzenia UE w 2004 roku, kluczowy element działań Brukseli wobec wschodnich sąsiadów stanowiło przekazywanie im unijnych rozwiazań ustrojowych. Temu celowi podporzadkowane było całe wypracowane przez Wspólnotę, przy wsparciu Polski, instrumentarium: umowy stowarzyszeniowe, wsparcie finansowe, polityka Partnerstwa Wschodniego. Negujacc dokonania własnej transformacji, a także podważając słuszność unijnego modelu liberalnej demokracji, rząd Polski stracił zarówno własną motywację, jak i legitymację ze strony partnerów do wspierania proeuropejskich reform na Wschodzie ${ }^{20}$.

Dziś polskie władze, jak się zdaje, nie przykładają wagi do tego, jakie konsekwencje będzie miała ich pasywność na poziomie europejskim. Tymczasem wycofanie się Polski $z$ aktywnego kierowania polityki wschodniej powoduje osłabienie lobby występującego na rzecz tego kierunku polityki zagranicznej UE. Sprzyja to przesuwaniu uwagi Wspólnoty ku innym jej sąsiadom: Bałkanom i krajom Afryki Północnej. Taka postawa Warszawy powoduje także wzrost znaczenia Berlina, a jednocześnie zwiększa jego osamotnienie w działaniach wobec Ukrainy czy Rosji. Efektem jest swoiste „odeuropeizowanie” polityki wschodniej. W coraz większym stopniu staje się ona domeną Niemiec, a w mniejszym - polityka całej Unii. To wszystko zaś jest na rękę Moskwie, która postrzega aktywność UE w Europie Wschodniej jako niepożądaną konkurencję dla swoich wpływów. Przy czym zdecydowanie woli rozmawiać o problemach regionu w formacie „międzymocarstwowym”, a nie w ramach dialogu ze zjednoczoną Europa ${ }^{21}$.

$Z$ drugiej strony ta sama władza podsyca w Polsce nastroje antyukraińskie i przymyka oko na propagandę inspirowana przez Kreml. Stawia w centrum relacji nie kwestie strategiczne, ale wspomniana już politykę historyczna, która formułowana jest w sposób bezkompromisowy i konfliktogenny. Przykładem tego sa przyjęte poprawki do ustawy o Instytucie Pamięci Narodowej. Działania podejmowane przez polski rzą $\mathrm{w}$ stosunku do Ukrainy sa przede wszystkim pochodna kreowanej od 2015 roku przez władzę nacjonalistycznej narracji, która

${ }^{20}$ K. Pełczyńska-Nałęcz, Polityka wschodnia $w$ chaosie, Fundacja im. Stefana Batorego, Warszawa, marzec 2018, s. 1; J.M. Fiszer, The 30th Anniversary of the Sejm and Senate Elections in 1989. Systemic Transformation in Poland and Its Consequences for Europe and the World, „Myśl Ekonomiczna i Polityczna” 2019, nr 3(66), s. 137-159; J.M. Fiszer, 30-ta rocznica wyborów do Sejmu i Senatu $w 1989$ roku. Transformacja ustrojowa $w$ Polsce $i$ jej konsekwencje dla Europy i świata, „Biuletyn Analiz i Opinii” 2019, nr 3, s. 1-18.

21 Ibidem. 
odnosi się nie tylko do Kijowa, ale także do szeregu innych zagranicznych partnerów. Przy czym rząd PiS i związane $z$ nim środowiska społeczno-polityczne w niewielki stopniu liczą się z konsekwencjami swoich działań na arenie międzynarodowej. Bezkrytycznie bowiem ufaja amerykańskiej potędze i sojuszowi Polski ze Stanami Zjednoczonymi.

\section{ZAKOŃCZENIE}

Świat dziś wyraźnie ewoluuje w kierunku multipolarnym i wielocywilizacyjnym, ale rola UE i w ogóle Zachodu na arenie międzynarodowej maleje. Zachód traci swoje gospodarcze, polityczne, demograficzne i moralne podstawy, a wraz $z$ tym przestaje być wzorcem rozwojowym dla świata. Unia Europejska mimo wielu problemów wciąż ma jednak potencjały, aby mogła stać się aktywnym podmiotem w systemie euroatlantyckim i w nowym ładzie globalnym. Musi się jednak sukcesywnie reformować, pogłębiać i poszerzać oraz doskonalić swój system polityczny i gospodarczy (być może w kierunku federalistycznym), aby stać się graczem światowym, tak w aspekcie geoekonomicznym, jak i geopolitycznym. Niezbędnym warunkiem dla umocnienia pozycji i roli Zachodu na arenie międzynarodowej jest również efektywny system euroatlantycki, w tym solidarność i współpraca wszystkich państw należących do NATO i Unii Europejskiej.

Jest to niezbędne, gdyż Zachód, który po kryzysie finansowo-gospodarczym $z$ lat 2008-2014 i prestiżowych porażkach dyplomatycznych, a w przypadku Stanów Zjednoczonych także wojskowych (w Iraku, Afganistanie) wyraźnie pogubił się. W Afganistanie talibowie odzyskuja stopniowo tereny utracone od czasu inwazji Amerykanów wspieranych przez sojuszników z NATO w 2001 roku po ataku Al-Kaidy na Word Trade Center. Trwająca już 19 lat wojna kosztowała amerykańskich podatników co najmniej 760 mld dolarów. Zginęło ponad 2300 żołnierzy, a niemal 20 tys. zostało rannych ${ }^{22}$. Doprowadziła też do podziałów wśród członków NATO i Unii Europejskiej, które pogłębił kryzys migracyjny w latach 2015-2016. Ujawniły się głębokie różnice stanowisk i interesów państw członkowskich, w tym także między Niemcami a Francją ${ }^{23}$. Wzmocnieniu pozycji i roli Za-

22 P. Jendroszczyk, Trump talibom nie ufa, „Rzeczpospolita”, 3 IX 2019, s. A8.

23 J. Ciesielska-Klikowska, Francja i Niemcy $w$ procesie integracji europejskiej $w$ latach 1992-2007, Wydawnictwo Uniwersytetu Łódzkiego, Łódź 2017; J.M. Fiszer, M. Czasak, Trójkąt Weimarski. Geneza i działalność na rzecz integracji Europy w latach 1991-2016, Instytut Studiów Politycznych PAN, Warszawa 2019. 
chodu na arenie międzynarodowej nie sprzyja też polityka prezydenta Donalda Trumpa wobec Europy oraz jego chimeryczny stosunek do NATO i Unii Europejskiej. Uważa on bowiem, że Europa nie sprawdziła się jako ważny aktor na scenie międzynarodowej, zaangażowany w rozwiązywanie problemów globalnych i gotowy brać większą odpowiedzialność za bieg wydarzeń w świecie. Trump również nie wykazuje zbytniej wrażliwości w kwestii spraw Europy Wschodniej, a zwłaszcza Ukrainy, co nie ułatwia rozwiązywanie konfliktów w tym regionie ${ }^{24}$.

Nie mogac się odnaleźć w dokonującej się przemianie ładu globalnego, a pozostając w defensywie wobec grupy BRICS, Zachód obrał Rosję za swego rywala, którego próbuje zepchnać na peryferie światowej polityki. Tymczasem Rosja pod rządami Putina staje się coraz silniejsza i aktywnie włącza się do globalnej rozgrywki, o czym świadczy dziś jej operacja wojskowa w Syrii i na Ukrainie. Dlatego też należy $z$ nia rozmawiać, a nie izolować na arenie międzynarodowej, bo to zmusza Rosję do działań agresywnych, czego przykładem jest wojna hybrydowa $z$ Ukraina, która może doprowadzić do zaostrzenia zimnej wojny w stosunkach międzynarodowych lub nawet do wybuchu trzeciej wojny światowej. Nawiasem mówiąc, w stosunkach międzynarodowych od dłuższego czasu mamy już do czynienia $z$ nowa, tzw. hybrydową zimna wojna, która toczy się głównie między Rosją a Zachodem, a zwłaszcza na linii Moskwa-Waszyngton. Owa hybrydowość oznacza stosowanie wielu różnych klasycznych i nieklasycznych, otwartych i skrytych, militarnych i niemilitarnych form oraz metod osiagania celów politycznych przez Rosję w konfrontacyjnych stosunkach międzynarodowych ${ }^{25}$.

Normalizacja stosunków między Zachodem i Rosja jest też koniecznym warunkiem do wyprowadzenia Ukrainy z głębokiego kryzysu społeczno-gospodarczego, która powinna jednak mieć prawo do swobodnego wyboru swoich ekonomicznych i politycznych partnerów ${ }^{26}$.

${ }^{24}$ R. Youngs, Europe's Eastern Crisssis. The Geopolities of Asymmetry, Cambridge University Press, Cambridge 2017, s. 123-127; A. Rinke, Migration, Sicherheit, Wirtschaft. Afrika wird zu einer Priorität der deutschen und europäischen Politik, „Internationale Politik” 2016, nr 6, s. 123-129; R. Alexander, Die Getriebenen, Merkel und die Flüchtlingspolitik: Report aus dem Innern der Macht, Siedler, München 2017; T.G. Grosse, Pokryzysowa Europa. Dylematy Unii Europejskiej, PISM, Warszawa 2018; R. Aleksander, Angela Merkel i kryzys migracyjny. Dzień po dniu, „Teologia Polityczna”, Warszawa 2017.

${ }^{25}$ R. Łoś, Soft power $w$ stosunkach międzynarodowych, Wydawnictwo Uniwersytetu Łódzkiego, Łódź 2017; J.S. Nye, Soft Power. The Means to Success in World Politics, New York 2004, s. 40-44; J.S. Nye, Przyszłość siły, Warszawa 2011.

${ }_{26}$ J. Mearsheimer, Why the Ukraine Crisis Is the West's Fault: The Liberal Delusions That Provoked Putin, „Foreign Affairs”, t. 93, nr 5, s. 1-16; S.F. Cohen, Patriotic Heresy vs. the New Cold War: Fallacies of US Policy May by Leading to War Wit Russia, „The Nation”, 
Zachód powinien nie tylko stosować sankcje wobec Rosji, które utrudniaja jej współpracę $z$ Ukrainą, ale także szukać rozwiązań politycznych i prawno-międzynarodowych dla ułatwienia rosyjsko-ukraińskiego dialogu i zakończenia tego konfliktu.

Tymczasem Unia Europejska przyzwyczajona do stosowania w polityce zagranicznej soft power ${ }^{27}$ i zmęczona trawiącymi ja kryzysami nie ma ani determinacji, ani świadomości rosnącego zagrożenia i ogląda się na Stany Zjednoczone, które dziś największe wyzwanie dla siebie upatruja w rywalizacji $z$ Chinami i koncentruja się na walce $z$ islamskim terroryzmem, też nie maja ochoty na angażowanie się w obronie demokracji na Ukrainie. W efekcie tego eskalacja przemocy ze strony Rosji, w tym zwłaszcza jednostronne zajęcie w marcu 2014 roku Krymu, nie spotkała się $z$ odpowiednio twarda odpowiedzią Zachodu. Świadczy to - moim zdaniem - o wyczerpaniu Stanów Zjednoczonych i Unii Europejskiej długotrwałym kryzysem finansowo-gospodarczym i imigracyjnym oraz pokazuje, że sojusz euroatlantycki również przeżywa głęboki kryzys i traci swoją strategiczną moc, co rozzuchwala Rosję. Władimir Putin straszy i stosuje wobec Zachodu wiele różnych, choć wzajemnie ze soba powiąanych, instrumentów politycznych, gospodarczych i wojskowych. W obecnie napiętej sytuacji międzynarodowej na świecie $z$ Rosją rządzona przez Władimira Putina i $z$ nim samym trzeba jednak rozmawiać. Rosję jak najszybciej trzeba zawrócić na właściwą drogę, uciekając się do różnych środków - dyplomatycznych, gospodarczych i wojskowych, a Ukrainie należy udzielić daleko idącej pomocy, aby nie stała się nowa Syrią w Europie. Ukraina bowiem bez zachodniej pomocy dyplomatycznej, wojskowej, gospodarczej i finansowej nie wygra wojny z Rosja, która mimo licznych problemów sukcesywnie umacnia swoja pozycję na arenie międzynarodowej w XXI wieku.

Ukraina ze względu na swoje położenie geopolityczne i geoekonomiczne, między Wschodem a Zachodem, jest w pewnym sensie również skazana na współpracę z Rosją i Polska, która może i powinna być jej adwokatem w procesie akcesji do NATO i Unii Europejskiej oraz pomostem w zbliżeniu z państwami Zachodu. Polska, która jest już

15 IX 2014, s. 3; P. Maciejewicz, Ukraina - terapia szokowa, „Gazeta Wyborcza”, 14-15 III 2015, s. 8.

27 B. Piskorska, Soft power w polityce UE wobec państw Partnerstwa Wschodniego, Wydawnictwo KUL, Lublin 2017, s. 11-13; O. Barburska, Polityka wschodnia Unii Europejskiej jako część składowa polityki zagranicznej UE, Oficyna Wydawnicza ASPRA-JR, Warszawa 2018, s. 136-140; M.K.D. Cross, J. Melissen (ed.), European Public Diplomacy. Soft Power at Werk, New York 2013, s. 111-112. 
dwadzieścia jeden lat w NATO i szesnaście lat w UE posiada przecież duże doświadczenie $\mathrm{w}$ negocjacjach i współpracy $z$ tymi organizacjami międzynarodowymi. Powinna przede wszystkim wspierać Ukrainę w daż̇eniu do zbliżenia ze strukturami euroatlantyckimi, nawet jeśli ze strony jej decydentów politycznych płyną sygnały o braku woli kontynuowania tej wizji. Ukraina zaś powinna to wykorzystać w swojej polityce zagranicznej i ściśle współpracować w tym zakresie $z$ Polska, a nie toczyć $z$ nami jałowe spory historyczne. Zgadzam się ze stanowiskiem wielu badaczy, że:

Partnerstwo polsko-ukraińskie ma wszelkie podstawy, aby funkcjonować, ale wymaga to odbudowy zaufania i zmiany sposobu komunikacji oraz niebagatelizowania przez stronę ukraińską problemów historycznych ${ }^{28}$.

Warto tutaj wspomnieć, że po upadku komunizmu Polska i cały region Europy Środkowej stały się beneficjentami ekspansji liberalnego internacjonalizmu i pomocy Zachodu, której Polska - w przeciwieństwie do Ukrainy - nie zmarnowała. Polska polityka zagraniczna i bezpieczeństwa po 1989 roku była mocno determinowana poczuciem geopolitycznego dylematu dużego kraju Europy Środkowej położonego między siłami Zachodu i Wschodu, co zaowocowało decyzją o akcesji do NATO i Unii Europejskiej. Jak trafnie zauważa Marek A. Cichocki:

Oddziaływanie ładu liberalnego na Polskę nie miało jednak wyłącznie charakteru geopolitycznego. Równie ważna była transformacja gospodarczo-ustrojowa, przeprowadzona zgodnie $z$ dominujacym wówczas paradygmatem neoliberalnym przy asyście głównych organizacji międzynarodowych. Celem tego procesu było zintegrowanie wychodzacej $z$ komunizmu Polski $z$ gospodarczym, instytucjonalnym i politycznym systemem porządku liberalnego oraz dostosowanie funkcjonowania państwa i społeczeństwa do liberalnych norm i praktyk ${ }^{29}$.

Cel ten udało się osiagnąć dzięki wsparciu polskich przemian przez Zachód, zwłaszcza przez zjednoczone Niemcy i Stany Zjednoczone oraz bierności osłabionej wówczas i niezdecydowanej pod rządami Borysa Jelcyna Rosji. Dziś sytuacja międzynarodowa w Europie i na świecie jest inna. Inna też jest Rosja pod rządami Putina, który prowadzi agresywna, neoimperialna politykę i $z$ Ukrainy tak łatwo nie zrezygnuje.

${ }_{28}$ W. Konończuk, Czas na doktrynę postgiedroyciowska wobec Ukrainy, „Nowa Europa Wschodnia” 2018, nr 1 (53), s. 30; T. Stępniewski, Miejsce Ukrainy w polityce wschodniej Polski po 2004 roku ..., s. 173-193; G. Motyka, Nieustający polsko-ukraiński spór o historie, „Sprawy Międzynarodowe” 2018, nr 1, s. 36-37.

${ }_{29}$ M.A. Cichocki, Kryzys światowego ładu liberalnego. Jego natura i znaczenie dla Polski, „Sprawy Międzynarodowe” 2019, nr 2, s. 43-45. 
W kontekście powyższego zgadzam się $z$ tezą sformułowana przez byłego ministra spraw zagranicznych Radosława Sikorskiego, który na łamach niedawno opublikowanej książki pisze, że:

Najbardziej dramatycznym dylematem dla Polski byłby powrót Rosji do wariantu siłowego przeciwko Ukrainie przy bierności Zachodu. Niepodległość Ukrainy jest dla naszego bezpieczeństwa ważniejsza niż bezpieczeństwo wielu formalnych sojuszników. Oddanie Ukrainy bez walki tworzyłoby ryzyko przegapienia ostatniej szansy na powstrzymanie Rosji. Ale wejście do wojny po stronie Ukrainy bez wsparcia Zachodu to $z$ kolei ryzyko krwawego konfliktu, którego Rosja, dysponując bronią atomową, nie może przegrać. W wypadku wojny rosyjsko-ukraińskiej Polska powinna wesprzeć Ukrainę wszelkimi metodami poniżej progu otwartej wojny $z$ Rosja, tak, aby ukraińskiemu ruchowi oporu dać szansę na wycieńczenie agresora, a sobie i reszcie Zachodu czas na dozbrojenie” ${ }^{30}$. Niestety, jak pisze Katarzyna Pełczyńska-Nałęcz: „Prowadzona obecnie polityka wschodnia Polski to igranie $z$ ogniem"31.

W świetle dramatycznych wydarzeń w Kijowie, na Krymie i w Donbasie, a także w Syrii, Iraku i Paryżu (zamachy terrorystyczne), wyraźnie uwidoczniły się też liczne mankamenty w działalności Unii Europejskiej i NATO oraz uległ osłabieniu system transatlantycki i jego prestiż na świecie ${ }^{32}$. Pokój i bezpieczeństwo Europy i świata są dziś poważnie zagrożone. Nasila się zimna wojna w relacjach między Wschodem i Zachodem. Niepokój budzą zwłaszcza takie zjawiska i procesy, jak: podważanie wiarygodności porozumień rozbrojeniowych, w tym dotyczacych nieproliferacji broni masowego rażenia, utrzymywanie się reżimów autorytarnych i postaw konfrontacyjnych, nieposzanowanie zasad prawa międzynarodowego, standardów demokratycznych, praw człowieka, mniejszości etnicznych i religijnych, nasilajacy się międzynarodowy terroryzm i zorganizowana przestępczość.

Napawa jednak pewnym optymizmem fakt, że przywódcy UE i NATO maja już dziś świadomość tych zagrożeń i dostrzegaja nie tylko swoje słabości, ale także ich przyczyny. Zacieśniają współpracę i stopniowo modyfikuja politykę UE i NATO wobec Rosji oraz Ukrainy oraz w sferze bezpieczeństwa międzynarodowego. Unia Europejska i NATO powoli odchodzą od promowania się jako jedynie projektu pokojowego, w praktyce odwołującego się tylko do soft power, w kierunku pod-

30 R. Sikorski, Polska może być lepsza, Znak Horyzont, Warszawa 2018, s. 380.

31 K. Pełczyńska-Nałęcz, Polityka wschodnia w chaosie..., s. 3. Zob. także: K. Pełczyńska-Nałęcz, Polska wobec Rosji. Radykalizm bez polityki, „Sprawy Międzynarodowe” 2018, nr 3, s. 31-41.

32 J. Joffe, Ziemlich ungleiche Freunde, https://www.ipg-journal.de/rubriken/europeische-integration/artikel/ziemlich-ungleiche-freunde-4728/-utm-de_402020210208/utm _mediamt=newsleter. 
miotu współzawodniczącego geopolitycznie o wpływy. Świadczy o tym chociażby odniesienie w Globalnej strategii UE, przyjętej w czerwcu 2016 roku, do konieczności wzmocnienia soft power o twardy wymiar siły (hard power) ${ }^{33}$. Znalazło to również wyraz w orędziu o stanie UE wygłoszonym przez przewodniczącą Komisji Europejskiej Ursulę von der Leyen na sesji plenarnej Parlamentu Europejskiego w dniu 16 września 2020 roku. W orędziu tym podkreślono m.in., że:

Unia musi nie tylko bardziej stanowczo reagować na wydarzenia na świecie, ale też pogłębiać i udoskonalać partnerstwa ze swoimi przyjaciółmi i sojusznikami. [...] Możemy z decyzjami Białego Domu w ostatnim czasie nie zawsze się zgadzać. Zawsze jednak będziemy cenić sojusz transatlantycki - opierajacy się na wspólnych wartościach i historii, która nas łączy oraz na nierozerwalnej więzi między naszymi narodami. [...] Będziemy również wspierać kraje Partnerstwa Wschodniego $[\ldots]^{34}$.

Unia Europejska stoi na stanowisku, że Partnerstwo Wschodnie nie jest skierowane przeciwko Rosji. Co więcej, wielu unijnych polityków uważa, że współpraca UE z Ukrainą i Rosją nie wykluczają się wzajemnie, że nie jest to alternatywa $z$ rodzaju „albo Rosja albo Ukraina”. Kanclerz Angela Merkel i prezydent Francji Emmanuel Macron opowiadaja się za środkami dyplomatycznymi i wykluczaja działania militarne oraz kieruja się przekonaniem, że Europa skazana jest na współpracę $z$ Federacja Rosyjska, gdyż od tego zależy dobrobyt i bezpieczeństwo naszego kontynentu ${ }^{35}$.

Jak już wcześniej pisałem, Polska również aktywnie wspiera politykę UE na rzecz bezpieczeństwa i współpracy w Europie oraz jej wysiłki mające na celu zakończenie konfliktu Ukrainy z Rosja. Dała temu też wyraz niedawna wizyta prezydenta Rzeczypospolitej Polskiej Andrzeja Dudy na Ukrainie i podpisana 12 października 2020 roku z prezydentem Ukrainy Wołodymyrem Zełenskim wspólna deklara$\mathrm{cja}^{36}$, w której stwierdzono:

${ }^{33}$ F. Mogherini, Foreword, w: Shared Vision, Common Action: A Stronger Europe, Komisja Europejska, Bruksela 2016; A. Woźniak, Unia potrzebuje reformy, „Rzeczpospolita”, 14 V 2019, s. A26.

${ }_{34}$ Orędzie o stanie Unii wygłoszone przez przewodniczaca Ursule von der Leyen na sesji plenarnej Parlamentu Europejskiego, Bruksela, 16 września 2020.

35 A. Bielawska, Niemiecka chadecja wobec konfliktu rosyjsko-ukraińskiego, „Rocznik Integracji Europejskiej” 2015, nr 9, s. 338; J.M. Fiszer, T. Stępniewski, Polska i Ukraina $w$ procesie transformacji, integracji i wyzwań dla bezpieczeństwa Europy Środkowo-Wschodniej, Instytut Studiów Politycznych PAN, Warszawa 2017, s. 155-170.

36 Wspólna deklaracja Prezydenta Rzeczypospolitej Polskiej Andrzeja Dudy i Prezydenta Ukrainy Wołodymyra Zełenskiego, Oficjalna strona Prezydenta Rzeczypospolitej Polskiej /Aktualności/ Wypowiedzi Prezydenta RP/ Wystapienia, prezydent.pl. 
Podkreślamy znaczenie polsko-ukraińskich stosunków dwustronnych, które maja charakter partnerstwa strategicznego. [...] Rzeczpospolita Polska potwierdza wsparcie dla suwerenności i integralności terytorialnej Ukrainy w jej uznanych międzynarodowo granicach. [...] Potwierdzamy gotowość obu krajów do współpracy w celu dalszego pogłębienia stosunków Ukrainy z Unią Europejska na zasadach stowarzyszenia oraz głębokiej integracji ekonomicznej. [...] Ukraina wyraża wdzięczność Rzeczypospolitej Polskiej za praktyczne wsparcie aspiracji euroatlantyckich Ukrainy [...] Rzeczpospolita Polska wspiera pogłębienie współpracy Ukrainy z inicjatywą Trójmorza ${ }^{37}$.

Jak już wcześniej pisałem, Polska powinna konsekwentnie wspierać starania Ukrainy o członkostwo w NATO i Unii Europejskiej, gdyż leży to w interesie naszego bezpieczeństwa oraz pokoju w Europie i na świecie. Powinna też nadal aktywnie wspierać politykę wschodnia Unii Europejskiej, zwłaszcza wobec Ukrainy, gdyż będzie to mobilizowało Zachód do angażowania się w sprawy tego państwa i hamowało neoimperialna politykę Rosji wobec tego regionu, która zagraża nie tylko Ukrainie, ale również Polsce. 